\title{
MOMOSE'S HYDROCINNAMIC ACID REACTION ON DYSENंTERY BACILLI
}

\author{
TomoJI TANI AND Tsutomu YOSHIDA \\ The Department of Bacteriology, Faculty of Medicine, \\ Kanazawa University, Japan \\ (Received July 7th, 1952)
}

While investigating the growth inhibitory influence of aromatic acids on various strains of microorganisms, Momose observed and reported in 1930 that pseudodysentery bacilli when grown on agar medium containing hydrocinnamic acid or its sodium salt, stained the medium in reddish brown, while those strains of shigella, typhoid, paratyphoid A, B, and coli groups did not show this coloring reaction in spite of the cultivation done in the same manner. No follow-ups have been made on this reaction and it appears that the problems on pigment formation of dysentery bacilli have been ignored.

While transplanting stock cultures on agar medium since 1943, in our laboratory, some strains of dysentery bacilli were found to color their medium in reddish brown. Upon investigating the cause for this coloring, it was found that the coloring appeared only when Japenese meat extract "Render" was used in the preparation of the medium.

Being hinted by the above mentioned Momose's paper, the presence of hydrocinnamic acid was suspected. When its isolation was attempted a certain substance, the melting point of which was the same as that of hydrocinnamic acid, was obtained.

The agar medium added with this substance was recognized to present exactly parallel coloring reaction as that observed with the medium containing Render meat extract or hydrocinnamic acid. Therefore, the coloring reaction of Render meat extract was found, as reported by Momose, due to the existence of hydrocinnamic acid.

The medium used was prepared in the following manner in order to facilitate the observation of this coloring reaction:

Pepton $20 \mathrm{gm}$, sodium chloride $5 \mathrm{gm}, 10 \%$ alcohol solution of hydrocinnamic acid $1.5 \mathrm{ml}$ (approximately $1 / 1000 \mathrm{Mol}$ ), agar 20-30 $\mathrm{gm}$, aqua distillata $1000 \mathrm{ml}$ and $\mathrm{pH}$ was adjusted to 7.2-7.4. 
When dysentery bacilli are grown on this medium for approximately 20 hours at $37^{\circ} \mathrm{C}$ and left standing for additional 10 hours at room temperature, the coloring of medium becomes distinct. The coloring also appears but rather weakly when meat extract or meat infusion is added to the above medium. The coloring of medium starts with light pink color surrounding colonies and, following the elapse of time, becomes red spreading all over the slant surface. The coloring was the most intense when left standing for 2 to 3 days at room temperature. Thereafter, changing gradually into brown disappeared by the end of 10 days. Further, the colonies themselves were found stained in faint brown.

Under anaerobic cultivation, this coloring reaction does not take place, but as soon as this medium is exposed to the air, it shows red coloring. The coloring reaction is not influenced by the brightness of light. Optimal cultivation temperature for the coloring reaction is $30^{\circ} \mathrm{C}$ rather than $37^{\circ} \mathrm{C}$. Optimal initial $\mathrm{pH}$ of the medium stands between 7.0 to 7.5. Presence of any saccharides, which will subsequently be decomposed by the bacilli, retards the coloring reaction. This is because the medium is acidified, so that, as soon as the medium is alkalized the coloring appears. The pigment produced is easily soluble in water, slightly in methanol and ethanol but absolutely insoluble in any other organic solvents. The pigment loses its color and changes into yellow when the medium is strongly acidified or alkalized, but returns to reddish brown again when the medium is reduced to weak alkaline. Thus, the reaction is reversible. No appreciable change in the coloring will be produced by boiling of the pigment for 30 minutes at $100^{\circ} \mathrm{C}$.

\section{Hydrocinnamic Acid Reaction of Dysentery Bacilli}

Results of the experiments made with standard strains of the International Classification are shown in Table 1. Namely, in group A, only type 2 was found positive in hydrocinnamic acid reaction, all the other types being negative. The majority of strains in group B were positive, except type 3 (subtype $3 \mathrm{a}$ in Japan) and type 6 . Strains of group $\mathrm{C}$ were all negative. Both phase I and phase II of group D were positive. Results of the tests made on 1,841 strains of dysentery bacilli recovered from the patients and carriers were exactly the same to those of the standard strains, while some strains of type 3 of group B showed positive reaction (the majority of these strains belong to so called subtype $3 \mathrm{~b}$ in 
Japan). Certain strains of type 4 in group $B$ showed negative reaction and the decision of subtype for those strains is now under investigation.

Table 1. Hydrocinnamic acid reaction of the standard strains of dysentery bacilli in the International Classification

\begin{tabular}{|c|c|c|c|c|c|}
\hline Groups & \multicolumn{2}{|c|}{ Strains } & $\begin{array}{l}\text { Type or } \\
\text { Subtype }\end{array}$ & Strain No. & $\begin{array}{l}\text { HCA-reac- } \\
\text { tion }\end{array}$ \\
\hline A & $\begin{array}{c}\text { Shigella } \\
\text { " } \\
\text { " } \\
\text { " } \\
" \\
"\end{array}$ & $\begin{array}{c}\text { Aysenteriae } \\
" \\
" \\
" \\
" \\
"\end{array}$ & $\begin{array}{l}1 \\
2 \\
3 \\
4 \\
5 \\
6 \\
7\end{array}$ & $\begin{array}{r}1199 \\
1684 \\
177249 \\
75 \\
76 \\
77 \\
78\end{array}$ & $\begin{array}{l}- \\
+ \\
- \\
- \\
-\end{array}$ \\
\hline B & $\begin{array}{c}\text { Shigella } \\
\text { " } \\
" \\
" \\
" \\
" \\
" \\
" \\
" \\
"\end{array}$ & $\begin{array}{c}\text { flexneri } \\
\text { " } \\
" \\
" \\
" \\
" \\
" \\
" \\
" \\
\text { " }\end{array}$ & $\begin{array}{c}1 \mathrm{a} \\
1 \mathrm{~b} \\
2 \mathrm{a} \\
2 \mathrm{~b} \\
3 \\
4 \mathrm{a} \\
4 \mathrm{~b} \\
4 \mathrm{c} \\
5 \\
6 \\
\text { Variant X } \\
\text { " } \quad \mathrm{Y}\end{array}$ & $\begin{array}{r}1701 \\
1674 \\
1675 \\
\mathrm{PR} \\
102349 \\
95649 \\
94949 \\
1583 \\
63 \\
7 \\
\mathrm{X} 1677 \\
\mathrm{Y} 1678\end{array}$ & $\begin{array}{l}+ \\
+ \\
+ \\
+ \\
+ \\
+ \\
+ \\
+ \\
+ \\
+ \\
+ \\
+\end{array}$ \\
\hline C & $\begin{array}{c}\text { Shigella } \\
\text { " } \\
" \\
" \\
" \\
"\end{array}$ & $\begin{array}{c}\text { boydii } \\
\Rightarrow \\
" \\
" \\
" \\
"\end{array}$ & $\begin{array}{l}1 \\
2 \\
3 \\
4 \\
5 \\
6 \\
7\end{array}$ & $\begin{array}{r}65 \\
66 \\
67 \\
148 \\
295 \\
70 \\
1130\end{array}$ & $\begin{array}{l}- \\
- \\
- \\
- \\
- \\
-\end{array}$ \\
\hline D & $\begin{array}{c}\text { Shigella } \\
"\end{array}$ & $\begin{array}{c}\text { sonnei } \\
"\end{array}$ & $\begin{array}{c}\text { Phase I } \\
\# \quad \text { II }\end{array}$ & $\begin{array}{r}1196 \\
37148\end{array}$ & $\begin{array}{l}+ \\
+\end{array}$ \\
\hline
\end{tabular}

Table 1.

\section{Hydrocinnamic Acid Reaction of Other Bacteria}

All the strains of Salmonella did not show this coloring reaction nor did cholera bacilli, while 199 out of 5,519 strains (3.6\%) of Escherichia coli showed positive reaction. This coloring reaction was negative with all the strains of Micrococcus, Corynebacterium, Malleomyces, Pseudomonas, Serratia, Klebsiella and Proteus. 


\section{Differential Medium Utilizing Hydrocinnamic Acid Reaction}

On the basis of the fact that hydrocinnamic acid reaction is almost specific to dysentery bacilli, a differential medium has been prepared by adding hydrocinnamic acid to Kligler's medium in order to differentiate dysentery bacilli from other enteric bacteria and much convenience has been obtained by its application in practice.

Preparation of the medium:

$\begin{array}{lr}\text { Pepton (Teruuchi) } & 20 \mathrm{gm} \\ \text { Sodium chloride } & 5 \mathrm{gm} \\ \text { Agar } & 20 \mathrm{gm} \\ \text { Aqua distillata } & 1,000 \mathrm{ml}\end{array}$

Dissolve the above by boiling and adjust $\mathrm{pH}$ to $7.4-7.6$, then add following substances:

\begin{tabular}{lr} 
Lactose & $10 \mathrm{gm}$ \\
Glucose & $1 \mathrm{gm}$ \\
$\mathrm{FeSO}_{4} \cdot 7 \mathrm{H}_{2} \mathrm{O}$ & $0.2 \mathrm{gm}$ \\
$\mathrm{Na}_{2} \mathrm{SO}_{4}$ (anhydrous) & $0.4 \mathrm{gm}$ \\
$\mathrm{Na}_{2} \mathrm{~S}_{2} \mathrm{O}_{3} \cdot 5 \mathrm{H}_{2} \mathrm{O}$ & $0.08 \mathrm{gm}$ \\
Hydrocinnamic acid (10\% alcohol & $1.5 \mathrm{ml}$ \\
\multicolumn{1}{c}{ solution) } & \\
Bromthymol blue $(0.2 \%$ solution) & $4 \mathrm{ml}$
\end{tabular}

Boil for 1-2 minutes, adjust the volume, then readjust $\mathrm{pH}$ to 7.4-7.6. Dispense into small test tubes of a diameter $12 \mathrm{~mm}$ each in an amount of $3 \mathrm{ml}$, and sterilize 3 times each for 15 minutes at $100^{\circ} \mathrm{C}$, allow to coagulate keeping $1 / 3$ of the lower part of the medium deep and slanting $2 / 3$ of the upper part. For inoculation, stab the test organisms into the deep layer of the medium and smear the same on the surface of the slanted portion. Incubate the tubes for 20 hours at $37^{\circ} \mathrm{C}$ and replace them into an incubator

Table 2. Cultural findings on the differential medium

\begin{tabular}{|c|c|c|c|}
\hline \multirow{2}{*}{ Strains inoculated } & \multicolumn{3}{|c|}{ Cultural findings } \\
\hline & Slant surface & Deep layer & $\mathrm{H}_{2} \mathrm{~S}$ \\
\hline $\begin{array}{l}\text { Shigella (HCA-reaction positive) } \\
\Rightarrow " \text { ( } " \text { negative) } \\
\text { Salmonella typhosa } \\
\Rightarrow \text { paratyphi A } \\
\# \text { Escherichia coli" B }\end{array}$ & $\begin{array}{l}\text { Purple } \\
\text { Blue } \\
\text { Blue } \\
\text { Blue } \\
\text { Blue } \\
\text { Yellow }\end{array}$ & $\begin{array}{l}\text { Yellow } \\
\text { Yellow } \\
\text { Yellow } \\
\text { Yellow (gas) } \\
\text { Yellow (gas) } \\
\text { Yellow (gas) }\end{array}$ & $\begin{array}{l}- \\
\overline{+} \\
- \\
+\end{array}$ \\
\hline
\end{tabular}


adjusted at $20^{\circ}-25^{\circ} \mathrm{C}$. Approximately 10 hours later, distinct purple coloring will appear. Results of the examinations made with this medium are as shown in Table 2.

\section{SUMMARY}

Certain strains of dysentery bacilli, when grown on agar medium containing hydrocinnamic acid, present reddish brown coloring reaction which is considered available for differentiation of dysentery bacilli. A description was made herein on a differential medium devised by utilizing this reaction.

\section{REFERENCE}

Momosé, M.: On the effect of organic acids and their sodium salts upon various bacteria. Eiseigaku-Densembyogaku Zasshi, 26, 609-664, 1930 (in Japanese) 